\title{
Larvicidal activity, molluscicide and toxicity of the essential oil of Citrus limon peels against, respectively, Aedes aegypti, Biomphalaria glabrata and Artemia salina
}

Paulo Roberto Barros Gomes ${ }^{1+(\mathbb{D})}$, Marlucy Bezerra Oliveira ${ }^{2}$, Dionney Andrade de Sousa ${ }^{2}$ (i) , Jeremias Caetano da Silva ${ }^{1}$, Romer Pessôa Fernandes ${ }^{2}$, Hilton Costa Louzeiro ${ }^{3}$, Rayone Wesly Santos de Oliveira2 ${ }^{\circledR}$, Maria do Livramento de Paula4(i), Victor Elias Mouchrek Filho2(iD), Maria Alves Fontenele ${ }^{5}$ (i)

1 Federal Institute of Pará - Câmpus Abaetetuba, Teaching, Research and Extension Coordination, 3322 Rio de Janeiro Ave., Abaetetuba, Pará, Brazil.

2 Federal University of Maranhão, Department of Chemical Technology, 1966 dos Portugueses Ave., 1966, São Luís, Maranhão, Brazil

3 Federal University of Maranhão, Natural Sciences Degree Coordination, Pinheiro, Maranhão, Brazil

4 Federal University of Maranhão, Department of Pharmacy, 1966 dos Portugueses Ave., São Luís, Maranhão, Brazil

5 Federal University of Maranhão, Food Engineering Coordination, Imperatriz, Maranhão, Brazil

+Corresponding author: Paulo Roberto Barros Gomes, Phone: +55 98981016397 email address: prbgomes@yahoo.com.br

\section{ARTICLE INFO}

\section{Article history:}

Received: February 24, 2018

Accepted: July 24, 2019

Published: October 1, 2019

\section{Keywords:}

1. limonene

2. Aedes aegypti

3. volatile compounds

4. hydrodistillation

5. Biomphalaria glabrata
ABSTRACT: In this present work, we tested the larvicidal activity, molluscicide and toxicity of the oil extracted from Citrus limon peels, respectively against third stage larvae of Aedes aegypti, snail Biomphalaria glabrata, and Artemia salina. For this, we extract the essential oil by hydrodistillation. Then, we identified and quantified the components by gas chromatography coupled to mass spectrometry (GC-MS). We tested the larvicidal and molluscicidal activity, respectively, using the method adopted by the Brazilian Ministry of Health and the World Health Organization. We calculated the lethal concentration $\left(\mathrm{LC}_{50}\right)$ from the Probit method for the three biological activities with $95 \%$. The results of the chromatographic analysis showed that the oil has $58.81 \%$ of Limonene (major constituent) and $0.11 \% \alpha$-Mulene (minority component). The essential oil presented lethal concentration $\left(\mathrm{LC}_{50}\right)$ for larvicidal activity, molluscicide and toxicity, respectively at $15.48,13.05 \mathrm{and} 743.35 \mathrm{mg} \cdot \mathrm{L}^{-1}$. Therefore, the essential oil is active against larvae of $A$. aegypti and snail B. glabrata and non-toxic against larvae of $A$. salina.

\section{Biological activity essential oil}
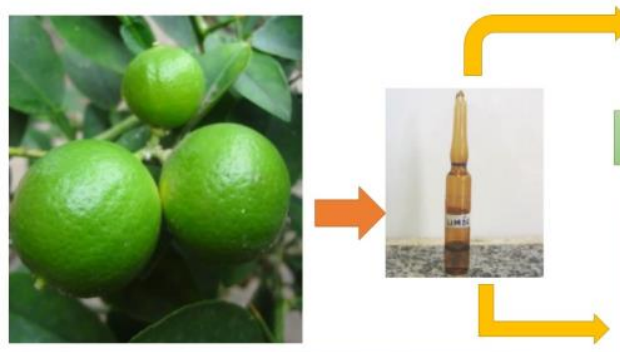

Extraction of essential oil from leaves of Citrus limon

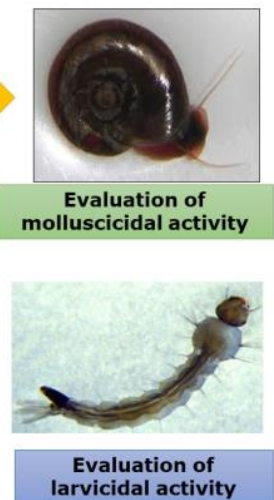

\section{Introduction}

The essential oils extracted from citrus plants arouse in man the interest in identifying his constituents and the possible applications to society. Among the identified compounds, the main ones are limonene, $\beta$-myrene, $\alpha$-pinene, $p$-cymene, $\beta$-pinene, terpinolene ${ }^{1-3}$, and its applications are in medicine, food, cosmetics, detergents, 
limonene is the major component of oils from lemon peel (Citrus limon) and orange peel and of the essential oil of Carum carvi, being responsible for the prevention of dehydration and inhibition of microbial growth ${ }^{4}$.

In the literature, it was observed that the limonene was found to have larvicidal and molluscicidal activity against Dysmicoccus brevipes $^{5}$ and Lymnaea acuminata ${ }^{6}$. Based on this information, we asked: did the essential oil extracted from the bark of $C$. limon have larvicidal activity against the third stage larvae of Aedes aegypti and molluscicide against the snail Biomphalaria glabrata, both disease vectors, respectively, dengue and schistosomiasis? Therefore, the fight against the vectors of dengue and schistosomiasis occur through, respectively, larvicides and synthetic molluscicides. Among the larvicides and molluscicides recommended by the World Health Organization (WHO), are, respectively, the temephos and niclosamide? However, the use of these larvicides and molluscicides provokes resistance of larvae and snails, low selectivity, environmental contamination and high $\operatorname{cost}^{8-10}$. Thus, it is recommended studies of extracts of plants ${ }^{7}$ and larvicides.

There are two essential points in the manual of the World Health Organization (WHO) ${ }^{11}$ on the efficacy of a plant's molluscicidal activity, although the same does not exist for larvicidal activity. One is about the activity of the extracts. These are considered to be active when the $24 \mathrm{~h}$ shellfish mortality is equal to or greater than $90 \%$ at the concentration of $20 \mathrm{ppm}$ for extracts and 100 ppm for the raw vegetable. Another is on toxicity and field studies. Even if the natural molluscicides are biodegradable, within the values required by the WHO, they may present risks?

In this context, in our toxicity study, we chose to carry it out with Artemia salina for two reasons. One, low cost, easy manipulation and a good indication of non-target organisms ${ }^{12,13}$. Another study, due to the good results of plants with the molluscicidal activity that used A. salina in the toxicities test ${ }^{14,15}$. Hence, in view of the above, we chemically characterized the essential oil extracted from the bark of $C$. limon and tested the larvicidal activity against larvae in the third stage of $A$. aegypti, molluscicidal activity against the snail $B$. glabrata and toxic activity against larvae $A$. salina.

\section{Materials and methods}

\subsection{Obtaining essential oil}

We collected the fruits, branches, and leaves of C. limon in the district of Sá Viana (January and June 2010), in the peripheral region of São Luís/MA, directly from the lemon tree, which is free of agricultural pesticides. In the Seabra Attic Herbarium (SLS) of the Federal University of Maranhão (UFMA), we identified this species from the observation and comparison with the part already identified in the herbarium under registration number 100379 (family Rutaceae, genus Citrus). After this step, we removed the fruit peels with a stylet.

To extract the essential oil, we used a glass Clevenger extractor coupled to a $1000 \mathrm{~mL}$ round bottom flask and to an electric blanket as a heat source. To each essential oil extraction routine, we weigh and grind in an electric sample mill $30 \mathrm{~g}$. After this step, we mixed the sample with distilled water in the proportion 1:10 and placed in a round bottom flask, coupled to the extractor system. Then we switched on the electric blanket and set the temperature to $100^{\circ} \mathrm{C}$. After $5 \mathrm{~h}$ the distillation was stopped, and the essential oil was collected. The oil is dried by means of percolation in anhydrous sodium sulfate. We performed these operations in triplicates and stored the samples in ampoules of amber glass under refrigeration (temperature of 15 $\left.{ }^{\circ} \mathrm{C}\right)$ to avoid possible losses of volatile constituents. So, we determined the density of the essential oil extracted from the use of a $1.0 \mathrm{~mL}$ pycnometer, previously dried, tared and calibrated.

\subsection{Chemical analysis}

For the chemical analysis, we used the gas chromatographic technique coupled to the electron impact mass spectrometer and ion trap analyzer (GC/MS). The equipment used was of the Varian 2100 brand, using helium as drag gas with flow in the column of $1 \mathrm{~mL} \mathrm{~min}^{-1}$; injector temperature $270{ }^{\circ} \mathrm{C}$, split 1:50; $(15 \mathrm{~m} \times 0,25 \mathrm{~mm})$ with stationary phase VF-1ms $(100 \%$ methylsiloxane $0.25 \mu \mathrm{m}$ ) and oven temperature programming of 60 to $200^{\circ} \mathrm{C}$ with a heating rate of $8{ }^{\circ} \mathrm{C} \mathrm{min}^{-1}$ and 200 $290{ }^{\circ} \mathrm{C}$ with heating rate of $15^{\circ} \mathrm{C} \mathrm{min}^{-1}$. In the mass spectrometer the manifold, ion trap, and transfer line temperatures were 50,190 and $200{ }^{\circ} \mathrm{C}$, respectively. $1.0 \mu \mathrm{L}$ (automatic injector CP-8410) aliquots of the samples diluted in the proportion of 
$20 \mu \mathrm{L}$ in $1.5 \mathrm{~mL}$ of hexane were injected. We have identified the components of the oil from the comparison of these with the data obtained from authentic substances in reference libraries ${ }^{16}$.

\subsection{Collection and cultivation of Aedes aegypti larvae}

In this way, we collected eggs at the Federal University of Maranhão, Bacanga Campus in São Luís Maranhão, through traps called ovitraps. These consist of black polyethylene pails with a capacity of $500 \mathrm{~mL}$ each, where we put water and insert two eucatex vanes into the mosquito. We inspect the traps weekly for replacement of the reeds and egg collection. After this step, we placed A. aegypti eggs to hatch at a temperature of $31{ }^{\circ} \mathrm{C}$ in a $200 \mathrm{~mL}$ polyethylene vessel with mineral water. We fed the larvae with cat food until they reached the third stage, when the experiments were done.

\subsection{Test of larvicidal activity}

We prepared a $1,000 \mathrm{mg} \cdot \mathrm{L}^{-1}$ stock solution from the $50 \mathrm{mg}$ weighing of the oil into a solution of $49.75 \mathrm{~mL}$ of distilled water and $0.25 \mathrm{~mL}$ of Tween80. From this, we prepared five solutions at the concentrations $5,10,30,50$ and $70 \mathrm{mg} \cdot \mathrm{L}^{-1}$. For each concentration, we used ten larvae and $30 \mathrm{~mL}$ of each solution in the cited concentrations. We performed all the tests in triplicate and as negative control we used a solution formed by $49.75 \mathrm{~mL}$ of water to $0.25 \mathrm{~mL}$ of Tween-80, and as a positive control, a solution of Temephos ([4-(4dimethoxyphosphinothioyloxyphenyl) sulfanylphenoxy]-dimethoxy-sulfanylidene- $\lambda^{5}$ phosphane), which is equivalent to the concentration used by the National Health Foundation (Funasa) for the larvicidal control of the vector, in addition to Novaluron (N-[[3-chloro4-[1,1,2-trifluoro-2-

(trifluoromethoxy)ethoxy]phenyl]carbamoyl]-2,6difluorobenzamide) at $0.02 \mathrm{mg} \cdot \mathrm{L}^{-1}$, a dose adopted by the Brazilian Ministry of Health, which indicates by the World Health Organization in the range of 0.01 to $0.05 \mathrm{mg} \cdot \mathrm{L}^{-1}$.

\subsection{Malacological investigation}

From this, we collected the samples of snails in the natural breeding sites of the neighborhood Sá Viana, the periphery of São Luís, Maranhão. The catch was carried out during rainy periods, with the use of PPEs (personal protective equipment), such as glove, boot seven leagues, and metal tongs. The collection technique consists of scraping the submerged areas with the shell and the collected snails were placed in a glass container with a lid, with water from the breeding site itself ${ }^{17}$. The search of the same ones was realized in several points of each breeding place, in order to obtain a good sampling. After collection, these were labeled by the breeder and taken to the laboratory for identification and analysis. From the technique of dissection of the genital apparatus ${ }^{18}$, we identified the snails as belonging to the family Planorbidae, genus Biomphalaria, species B. glabrata.

\subsection{Snails positivity test}

For instance, we placed five snails in clear glass vials ( $30 \mathrm{~mL}$ capacity) with $25 \mathrm{~mL}$ of dechlorinated water, that is $5 \mathrm{~mL}$ per snails, brought to light exposure (100 W lamps), at a distance of $30 \mathrm{~cm}$, during $1 \mathrm{~h}$, to stimulate the release of cercariae ${ }^{19}$. After exposure, the glasses were taken for analysis by means of a stereoscopic magnifying glass $8 x$. Those that were parasitized (positive) were labeled and separated for future individual analysis in order to verify which was contaminated and those that did not show signs of infection by the trematode in the period of 30 days were selected for the molluscicidal activity test. The period of analysis of the snails was every 7 days, for one month (30 days) to confirm the absence of larval stages.

So, after the positivity test, we placed the snails in polystyrene containers with dechlorinated water and fed with hydroponic lettuce for future test of molluscicidal activity.

\subsection{Molluscicidal activity test}

The molluscicidal activity was performed according to a manual described by the World Health Organization. To do this, we placed 10 adult snails, negative for Schistosoma mansoni in each beaker containing $500 \mathrm{~mL}$ of a solution obtained from the dilution of each oil with distilled water and $0.15 \mathrm{~mL}$ of Tween 80 (surfactant) at the concentrations of $100,75,50,25$, and $10 \mathrm{mg} \mathrm{L}^{-1}$, obtaining at the end a proportion of $50 \mathrm{~mL}$ of solution for each snail and feeding them with hydroponic lettuce ad libittum $^{20}$. They were exposed to the solution for $24 \mathrm{~h}$ at room temperature. After this period, the snails were 
removed from the solution and the snails were washed twice with dechlorinated water, placed in each beaker containing $500 \mathrm{~mL}$ of dechlorinated water, fed with hydroponic lettuce and observed every $12 \mathrm{~h}$ (method recommended $24 \mathrm{~h}$ ) for four days to assess mortality. To confirm the activity, we observe the mollusks. If the cephalopods mass is retracted into the shell, release the hemolymph, or swell and extend the cephalopod out of the shell, it is considered dead ${ }^{21}$.

\subsection{Toxicity test with Artemia salina}

So that, the Artemia salina Leach cysts were transferred to an aquarium containing the synthetic saline solution (60 $\mathrm{g}$ of sea salt / liter of distilled water) and oxygen saturation, obtained with the aid of an air pump. The aquarium was divided into two interconnected compartments, the cysts remaining in one of the compartments, leaving the second compartment under artificial illumination of a 100 W lamp. After $24 \mathrm{~h}$, the cysts hatched, the larvae migrated to the lighted compartment because they had phototropism positive. These were transferred to an aquarium containing synthetic saline and kept in incubation for another $24 \mathrm{~h}$ under the same lighting and oxygenation conditions. The methodology used was described by Meyer at $a l .{ }^{22}$ but with modifications.

For the evaluation of the lethality of A. salina Leach, $20 \mathrm{mg}$ of the oil was added to $0.02 \mathrm{mg}$ of Tween 80 , the volume was filled to $2 \mathrm{~mL}$ with artificial saline. This dilution was done to obtain a $10 \mathrm{mg} \mathrm{mL}^{-1}$ stock solution and a concentration of $0.1 \%$ Tween 80 . Samples of 5, 50, 250 and $500 \mu \mathrm{L}$ of this stock solution were transferred to vials with $5 \mathrm{~mL}$ of final solution, obtaining concentrations of $10,100,500$ and $1000 \mathrm{mg} \cdot \mathrm{L}^{-1}$, respectively. Ten larvae in the nauplii phase were transferred to each flask. White (saline) was made with $20 \mu \mathrm{L}$ and the negative control (saline and $0.1 \%$ Tween 80 ) was made with $20 \mu \mathrm{L}$. After $24 \mathrm{~h}$ of incubation, the live larvae were counted, considering those microcrustaceans that did not move during observation and with slight agitation of the flask. Thus, we adopted the criterion established by
Amarante et al. ${ }^{23}$, which consider $\mathrm{LC}_{50}$ samples less than $100 \mathrm{mg} \mathrm{L}^{-1}$, highly toxic; with $\mathrm{LC}_{50}$ between 100 and $500 \mathrm{mg} \cdot \mathrm{L}^{-1}$, moderately toxic; and $\mathrm{LC}_{50}$ greater than $500 \mathrm{mg} \cdot \mathrm{L}^{-1}$ nontoxic.

\subsection{Statistical analysis}

The statistical test used was Anova of single factor and Tukey's posterior test to identify significant differences. For the calculation of the lethal concentration $\left(\mathrm{LC}_{50}\right)$, we used the Probit method $^{24}$. For mortality results, we expressed these results with mean \pm standard deviation. For all statistical tests, we considered the significance of $p$ $\leq 0.05$.

\section{Results}

3.1 Evaluation of the chemical characteristics of the essential oils obtained by gas chromatography coupled to mass spectroscopy (GC/MS)

Before identifying and quantifying the components present in the oil, we performed the kinetic test for extraction in the time interval of 0.5 to $5 \mathrm{~h}$ to verify the best performance. From this test, we verified that from 3 to $5 \mathrm{~h}$, the oil yield remained constant, obtaining a volume of $0.35 \mathrm{~mL}$. We calculated the extraction yield from the mass we used, which was $30 \mathrm{~g}$ of the material, volume obtained after extraction, of the density measurement, which was $0.823 \mathrm{~g} \cdot \mathrm{mL}^{-1}$ and the formula expressed by the Brazilian Pharmacopoeia $^{52}$. From this, the result obtained was, respectively in the ratio mass / volume and mass / mass, of $1.17 \%$ and $0.96 \%$.

From this study, we identify and quantify the components present in the oil. The result of the GCMS analysis showed 23 peaks, which indicated the presence of 23 compounds (Fig. 1). In comparing the mass spectra of the constituents with the NIST 8 library, we identified the 15 compounds (Table 1). Based on the results, we observed that the major component is Limonene (58.81\%) and the minority is the $\alpha$-Mulene $(0.11 \%)$ (Table 1$)$. 


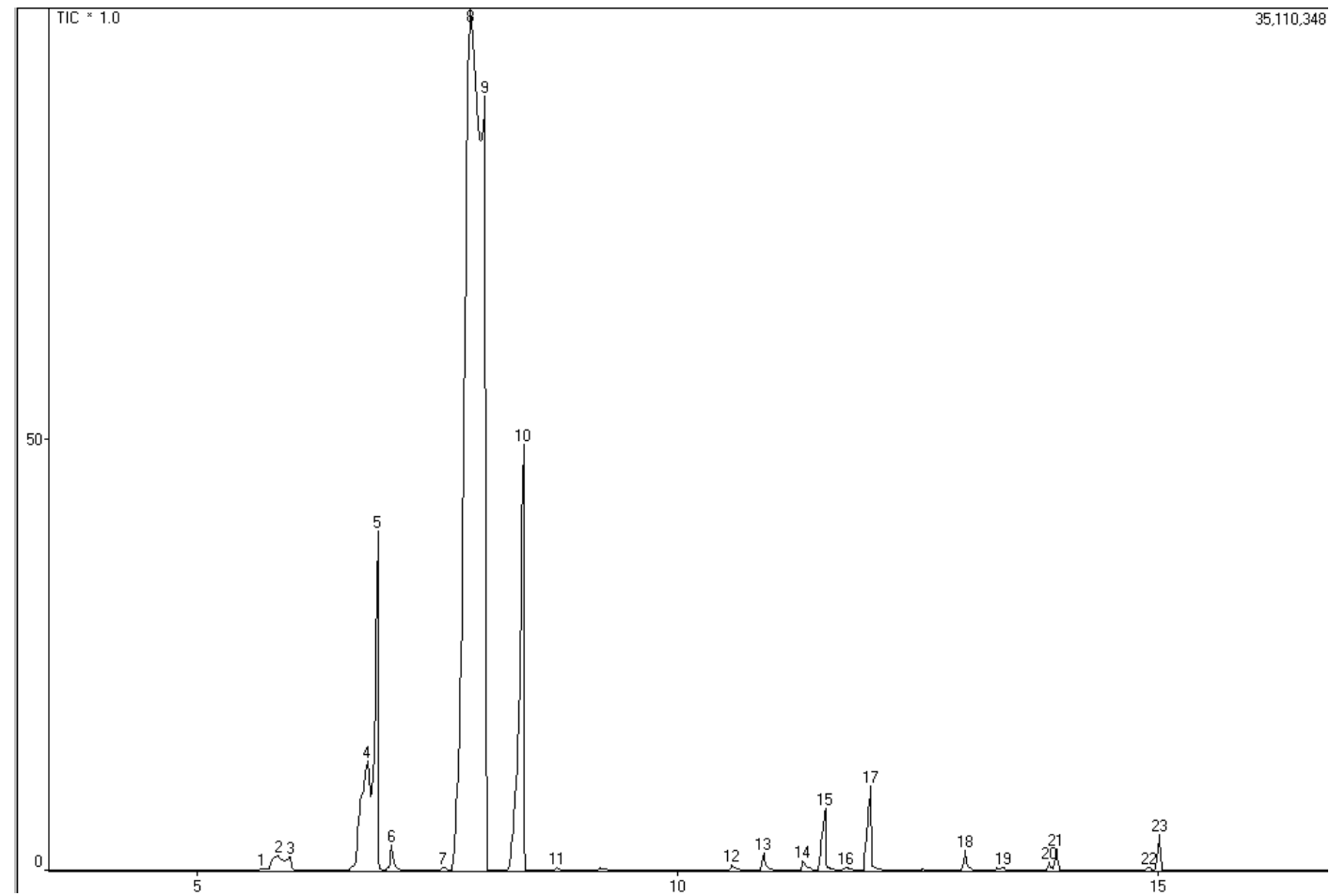

Figure 1. Citrus limon peel essential oil GC/MS Chromatogram.

Table 1. Compounds identified in the essential oil sample from Citrus lemon peel.

\begin{tabular}{|c|c|c|c|c|}
\hline Peak $^{\mathbf{1}}$ & R.T(min) & Components & Percentage (\%) & Quality $^{\mathbf{3}}$ \\
\hline 1 & 5.858 & $\alpha$-Pinene & 0.72 & 95 \\
\hline 2 & 6.775 & Sabinene & 5.08 & 92 \\
\hline 3 & 6.875 & $\beta$-Pinene & 4.91 & 93 \\
\hline 4 & 7.033 & $\beta$-Myrcene & 0.45 & 91 \\
\hline 5 & 7.845 & Limonene & 58.81 & 90 \\
\hline 6 & 8.408 & $\gamma$-Terpinene & 9.01 & 93 \\
\hline 7 & 10.575 & Terpine-4-ol & 0.13 & 89 \\
\hline 8 & 10.892 & $\alpha$-Terpinenol & 0.31 & 96 \\
\hline 9 & 11.308 & Trans-geraniol & 0.25 & 92 \\
\hline 10 & 11.525 & $\beta$-Citral (geranial) & 1.11 & 93 \\
\hline 11 & 12.000 & $\alpha$-Citral (geranial) & 1.61 & 92 \\
\hline 12 & 13.000 & Geranial acetate & 0.32 & 93 \\
\hline 13 & 13.400 & $\alpha$-Mulene & 0.11 & 92 \\
\hline 14 & 13.950 & Bergamolene & 0.29 & 92 \\
\hline 15 & 15.017 & $\beta$-Bisabolene (geranial) & 0.50 & \\
\hline
\end{tabular}

Note: ${ }^{1}$ Number of the peak in the column elution order; ${ }^{2} \mathrm{RT}$ : Retention time of the compounds. Quality ${ }^{3}$ : search index in the database that reflects the similarity of the mass spectrum obtained with the records in the libraries used.

\subsection{Larvicidal activity, molluscicide and toxicity}

We tested the larvicidal activity for concentrations of $5,10,30,50$ and $70 \mathrm{mg} \mathrm{L}^{-1}$, molluscicide for $10,25,50,75$ and $100 \mathrm{mg} \mathrm{L}^{-1}$ and toxicity for $10,100,500$ and $1000 \mathrm{mg} \mathrm{L}^{-1}$. In all tests, we observed an increase in the percentage of mortality with the increase in concentration and absence of interference of the biological activity in the control test. Thus, they were higher in 
concentrations of larvicidal activities, molluscicides and toxicity, respectively 70,50 and $1000 \mathrm{mg} \mathrm{L}^{-1}$. In addition, we observed that there were no significant differences between treatments
(Table 2). The $\mathrm{LC}_{50}$ values for larvicidal activities, molluscicides and toxicity are, respectively, 15.48 , 13.05 and $743.35 \mathrm{mg} \mathrm{L}^{-1}$ (Table 3).

Table 2. Results of the larvicidal, molluscicidal and toxicity activities of the essential oil of Citrus limon peels.

\begin{tabular}{|c|c|}
\hline \multicolumn{2}{|c|}{ Larvicidal activity } \\
\hline Concentration $\left(\mathrm{mg} \mathrm{L}^{-1}\right)$ & Mortality of larvae $(\%)$ \\
\hline 70 & $100.0 \pm 0.0^{\mathrm{a}}$ \\
\hline 50 & $86.7 \pm 0.4^{\mathrm{a}}$ \\
\hline 30 & $66.7 \pm 0.4^{\mathrm{a}}$ \\
\hline 5 & $36.7 \pm 0.4^{\mathrm{a}}$ \\
\hline \multicolumn{2}{|c|}{ Molluscicidal activity $^{\mathrm{a}}$} \\
\hline Concentration $\left(\mathrm{mg} \mathrm{L}^{-1}\right)$ & Mortality of snails $(\%)$ \\
\hline 100 & $100.0 \pm 0.0^{\mathrm{a}}$ \\
\hline 75 & $100.0 \pm 0.0^{\mathrm{a}}$ \\
\hline 50 & $100.0 \pm 0.0^{\mathrm{a}}$ \\
\hline 25 & $86.7 \pm 0.4^{\mathrm{a}}$ \\
\hline 10 & $26.7 \pm 0.4^{\mathrm{a}}$ \\
\hline \multicolumn{2}{|c|}{ Toxicity activity $^{-1}$} \\
\hline Concentration (mg L \\
\hline 1000 & Mortality of larvae $(\%)$ \\
\hline 500 & $100.0 \pm 0.0^{\mathrm{a}}$ \\
\hline 100 & $46.7 \pm 0.4^{\mathrm{a}}$ \\
\hline 10 & $13.3 \pm 0.4^{\mathrm{a}}$ \\
\hline \multicolumn{2}{|c|}{ differences (p <0.05). } \\
\hline \multicolumn{2}{|c|}{ mean values and the standard deviation of the } \\
\hline
\end{tabular}

Table 3. $\mathrm{LC}_{50}$ result of larvicidal activity, molluscicide and essential oil toxicity extracted from Citrus limon peel.

\begin{tabular}{|c|c|c|c|c|c|}
\hline $\begin{array}{c}\text { Biological } \\
\text { Activity }\end{array}$ & $\begin{array}{c}\text { Lethal } \\
\text { Concentration } \\
\left(\mathbf{L C}_{\mathbf{5 0}}\right) \\
\left(\mathbf{m g ~ L}^{-\mathbf{1}}\right)\end{array}$ & $\begin{array}{c}\text { Lower Limit } \\
\left(\mathbf{m g ~ L}^{-\mathbf{1}}\right)\end{array}$ & $\begin{array}{c}\text { Upper Limit } \\
\left(\mathbf{m g ~ L}^{\mathbf{- 1}}\right)\end{array}$ & $\begin{array}{c}\text { Standard } \\
\text { deviation } \\
(\mathbf{S D})\end{array}$ & $\begin{array}{c}\mathbf{R}^{\mathbf{2}} \\
(\text { Correlation) }\end{array}$ \\
\hline Larvicidal & 15.5 & 10.3 & 23.3 & 0.4 & 0.97 \\
\hline Molluscicidal & 13.1 & 9.5 & 18.0 & 0.2 & 1 \\
\hline Toxicity & 743.4 & 346.9 & 1593.0 & 0.7 & 1 \\
\hline
\end{tabular}




\section{Discussion}

From this study, we showed that the essential oil extracted from the bark of $C$. limon has larvicidal activity, molluscicide and toxicity. This may be a viable alternative to synthetic larvicides and molluscicides, since they would act against target organisms due to their toxicity against other organisms. We found that the percentage $(\mathrm{m} / \mathrm{v})$ of the oil yield was $1.17 \%$ and that the main components are limonene (major component) and $\alpha$-Mulene (minor component).

The yield that we obtained in a time of extraction of $5 \mathrm{~h}$ was $1.17 \%$, in which this value remained constant in the interval of 3 to $5 \mathrm{~h}$. The study of the yield allows to evaluate the time necessary to conserve the best characteristics of the oil. According to Mouchrek Filho ${ }^{25}$, quoted by Gomes et $_{\text {al. }}{ }^{26}$, a time of rapid extraction leads to a product with the predominance of more volatile constituents, but without the best characteristics. Otherwise, slow distillation overloads the product with undesirable flavors ${ }^{54}$. Generally, the best yields are obtained from the time of $3 \mathrm{~h}^{26-30}$.

From the chromatographic method coupled to the mass spectrometer, we identified and quantified limonene as the major component of the essential oil extracted from $C$. limon peels. Thus, we confirm what has already been described in the literature regarding this component for citrus substances. However, we observe that the quantity of this differs from other works, where they are generally above $^{31-33}$ and others below 50\%. The redirection of plant metabolic pathways to lead to the biosynthesis of different compounds ${ }^{34-36}$ and abiotic factors are responsible for caused changes in the composition of $C$. limon essential oil.

In the study of larvicidal activity, the essential oil was active against the third stage larvae of $A$. aegypti in the concentration of $70 \mathrm{mg} \cdot \mathrm{L}^{-1}$ with $100 \%$ mortality of the larvae tested. Although this result gives us a dimension of biological activity, a statistical calculation of the lethal concentration $\left(\mathrm{LC}_{50}\right)$ from the method of Finney ${ }^{24}$ gave us an estimate of inferring this result for a population, considering a statistical distribution of the normal type. The result of $\mathrm{LC}_{50}$ was $15.48 \mathrm{mg} \cdot \mathrm{L}^{-1}$. From this result, we compare the criteria adopted by Cheng et al. (2003), since up to the moment of this research there is no criterion established the World Health Organization ${ }^{37}$ to consider active larvicidal activity or inactive. According to the Cheng et al. ${ }^{38}$ the larvicidal activity of the essential oil is active when the $\mathrm{LC}_{50}<100 \mathrm{mg} \cdot \mathrm{L}^{-1}$; inactive when $\mathrm{LC}_{50}>$ $100 \mathrm{mg} \cdot \mathrm{L}^{-1}$ is highly active when $\mathrm{LC}_{50}<50 \mathrm{mg} \cdot \mathrm{L}^{-1}$. Thus, from this classification the essential oil we extract from the bark of $C$. limon is considered highly active.

The larvicidal activity of the essential oils are influenced by several factors. A study by Fernandez et al. $(2014)^{39}$ showed that larvicidal activity is higher in spring, summer and autumn, and lower in winter, confirming the influence of seasonality; for Leyva et al. ${ }^{40}$ synergistic action among metabolites (even in small proportions), the collection period and the extraction method are responsible for this; while other studies attribute this action to terpenes, alcohols, and aldehydes ${ }^{41-43}$.

For these reasons, the results of our study confirm the larvicidal and insecticidal activity of limonene of $C$. limon essential oil against the genus Aedes. The study carried out by Campolo et al. ${ }^{44}$ showed the activity of this oil against Aedes albopictus larvae with a lethal concentration $\left(\mathrm{LC}_{50}\right)$ of $145.27 \mathrm{mg} \mathrm{L}^{-1}$ after $24 \mathrm{~h}$ exposure. However, the study of larvae, pulps and adults of Aedes albopictus ${ }^{45}$ confirmed the activity of the oil with a lethal concentration $\left(\mathrm{LC}_{50}\right)$ of 35.99 and 34.89 $\mathrm{mg} \cdot \mathrm{L}^{-1}$ for the enantiometric forms of limonene, respectively, R - (+) - limonene and S - (-) limonene. Finally, the study Amer and Mehlhorn ${ }^{46}$ confirmed that activity against third-stage larvae of A. aegypti was higher at $24 \mathrm{~h}$ exposure time when compared to shorter times. Thus, the difference that these studies have with the results of our study is in the low value of the $\mathrm{LC}_{50}$ that we obtain. To explain this difference, we attribute seasonality, collection and extraction factors and synergism.

In relation to molluscicidal activity, the essential oil was active with $\mathrm{LC}_{50} 13.48 \mathrm{mg} \cdot \mathrm{L}^{-1}$. In this case, to affirm this, we compare the result obtained from the $\mathrm{LC}_{50}$ with the criteria used by the $\mathrm{WHO}^{11}$. According to this criterion, the extract obtained from the plant is active when it causes mortality of $90 \%$ of the aquatic mollusks at the $24 \mathrm{~h}$ exposure time, under constant temperature and concentration up to $100 \mathrm{mg} \cdot \mathrm{L}^{-147}$. Thus, we proved that the result we obtain from the $\mathrm{LC}_{50}$ of our study is within the limits established by the WHO.

Besides the molluscicidal activity which we show in this work, we observed in the literature that the limonene obtained from the Carum cravi seed powder showed activity against the snail Lymnaea acuminata $^{6}$. Although this component caused mortality of Lymnaea acuminata, the inference of 
the lethal concentration, $\mathrm{LC}_{50}$, for a population of these snails did not meet the criteria established by $\mathrm{WHO}^{11}$, whose value was $130.61 \mathrm{mg} \cdot \mathrm{L}^{-1}$ in the time of $24 \mathrm{~h}$. In addition, this study left craving for the percentage absence of limonene contained in the extracts, in which it left doubts about its effectiveness.

In the literature there are other plants that have molluscicidal activity against $B$. glabrata, however, the effectiveness is in the lowest value of the lethal concentration $\left(\mathrm{LC}_{50}\right)$. The study of thirteen Solanum species revealed that the extracts of the species $S$. asperum, $S$. diamantinese, $S$. paludosum, S. sisymbriifolium and S. stipulaceum present activity with lethal concentration $\left(\mathrm{LC}_{50}\right)$ varying from 20 to $50 \mathrm{mg} \mathrm{L}^{-1}{ }^{48}$; Moringa oleifera Lam seed extracts were active in the lethal concentration, $\mathrm{LC}_{50}, 419 \mathrm{mg} \mathrm{L}^{-1}{ }^{49}$; extracts from the stems of Melloa quadrivalvis and Tabebuia aurea and whole plants of Adenocalymma comosum, Arrabidaea parviflora, Cuspidaria argentea, and Clytostoma binatum have activity with $\mathrm{LC}_{50}$ concentration varying from 5.2 to 37.5 $\mathrm{mg} \mathrm{L}^{-1}$, being the most active Cuspidaria argentea, $\mathrm{LC}_{50} 5.2 \mathrm{mg} \mathrm{L}^{-1}{ }^{50}$; the essential oil of Pimenta dioica is active with $\mathrm{LC}_{50} 18.62 \mathrm{mg} \mathrm{L}^{-1}$, however the toxicity study showed that it is highly toxic to other organisms ${ }^{53}$. Though, the Ocotea bracteosa essential oil has activity with concentration, $\mathrm{LC}_{50}$ $4.6 \mathrm{mg} \mathrm{L}^{-151}$. Although $O$. bracteosa essential oil has good results in lethal concentration values, the absence of a study of toxic activity in this study raises doubts about its effectiveness in a real system.

Hence, faced with this impasse, when performing the study of toxicity, we evaluated the possibility of the action of oil against non-target organisms. In our study, we used A. salina because of the following characteristics: formation of dormant cysts, low cost, easy manipulation in the laboratory and indication of interference with nontarget organisms ${ }^{12,13}$. Based on the toxicity parameters of Amarante et al. ${ }^{23}$, the essential oil, with $\mathrm{LC}_{50}=743.35 \mathrm{mg} \mathrm{L}^{-1}$, is non-toxic $\left(\mathrm{LC}_{50}>500\right.$ $\left.\mathrm{mg} \mathrm{L}^{-1}\right)$. In addition to our study, we found in the literature extracts from six plants of the family Bignoniaceae that have moderate to low toxicity with $\mathrm{LC}_{50}$ values varying from 485.5 to $815.4 \mathrm{mg}$ $\mathrm{L}^{-150}$.

\section{Conclusions}

In this manner, according to the results obtained in this study, we can conclude that the essential oil extracted from the shells of $C$. limon has larvicidal activity and molluscicide, respectively, third stage larvae of $A$. aegypti and snails B. glabrata, and non-toxic front $A$. salina. In addition, we identified and quantified the majority and minority components, which were, respectively, limonene and $\alpha$-Mulene.

\section{References}

[1] Buettner, A., Mestres, M., Fischer, A., Guasch, J., Schieberle, P., Evaluation of the most odour-active compounds in the peel oil of clementines (Citrus reticulata Blanco cv. Clementine), Eur Food Res. Technol. $216 \quad$ (1) (2003) 11-14. https://doi.org/10.1007/s00217-002-0586-y.

[2] Caccioni, D. R., Guizzardi, M., Biondi, D. M., Agatino, R., Ruberto, G., Relationship between volatile components of citrus fruit essential oils and antimicrobial action on Penicillium digitatum and Penicillium italicum, Int J Food Microbiol 43 (1-2) (1998) 73-79. https://doi.org/10.1016/S01681605(98)00099-3.

[3] Sharma, N., Tripathi, A., Fungitoxicity of the essential oil of Citrus sinensis on post-harvest pathogens, World J. Microbiol. Biotechnol. 22 (6) (2006) 587-593. https://doi.org/10.1007/s11274-0059075-3.

[4] Demyttenaere, J., De Kimpe, N., Biotransformation of terpenes by fungi: Study of the pathways involved, J. Mol. Catal. B Enzym. 11 (4) (2001) 265-270. https://doi,org/10.1016/S1381-1177(00)00040-0.

[5] Martins, G. D. S. O., Zago, H. B., Costa, A. V., Araujo Junior, L. M. D., Carvalho, J. R. D., Chemical composition and toxicity of citrus essential oils on Dysmicoccus brevipes (Hemiptera: Pseudococcidae), Rev. Caatinga $30 \quad$ (3) (2017) 811-817. https://doi.org/10.1590/1983-21252017v30n330rc.

[6] Kumar, P., Singh, D. K., Molluscicidal activity of Ferula asafoetida, Syzygium aromaticum and Carum carvi and their active components against the snail Lymnaea acuminata, Chemosphere 63 (9) (2006) 15681574.

https://doi.org/10.1016/j.chemosphere.2005.08.071.

[7] Cantanhede, S. P. D., Marques, A. M., Silva-Souza, N., Valverde, A. L., Atividade moluscicida de plantas: 
uma alternativa profilática, Rev. Bras. Farmacogn. 20 (2) (2010) 282-288. https://doi.org/10.1590/S0102$695 \times 2010000200024$.

[8] Colley, D.G., Bustinduy, A. L., Secor, W. E., King, C. H., Human schistosomiasis, The Lancet 383 (9936) (2014) 2253-2264. https://doi.org/10.1016/S01406736(13)61949-2.

[9] Gasparotto Junior., A., Brenzan, M. A., Piloto, I. C., Cortez, D. A. G., Nakamura, C. V., Dias Filho, B. P., Rodrigues Filho, E., Ferreira, A. G., Estudo fitoquímico e avaliação da atividade moluscicida do Calophyllum brasiliense Camb (Clusiaceae), Quím Nova 28 (4) (2005) 575-578. https://doi.org/10.1590/S010040422005000400003.

[10] Diniz, M. M. C. S., Henriques, A. D. S., Leandro, R. S., Aguiar, D. L., Beserra, E. B., Resistance of Aedes aegypti to temephos and adaptive disadvantages, Rev Saúde Publica $48 \quad$ (2014) 775-782. https://doi.org/10.1590/S0034-8910.2014048004649.

[11] World Health Organization, Report of the Scientific working Group on Plant Molluscicide \& Guidelines for evaluation of plant molluscicides, Bull World Health Organ Geneva TDRSC (1983). https://apps.who.int/iris/handle/10665/60086.

[12] Utyama, I. K, A., Andrade, D., Watanabe, E., Pimenta, F. C., Ito, I. Y., Determinação da atividade antibacteriana e toxicidade do ácido acético e vinagres branco e tinto, Revista Eletrônica de Farmácia 4 (2) (2007) 202-207. https://doi.org/10.5216/ref.v4i2.3054.

[13] Calow, P., Marine and estuarine invertebrate toxicity tests, Hoffman Al Handb Cytotoxicology, Oxford, Blackwell, Sci Publication, 1993.

[14] Singh, A., Singh, S. K., Molluscicidal evaluation of three common plants from India, Fitoterapia 76 (7-8) (2005) $747-751$. https://doi.org/10.1016/j.fitote.2005.08.002.

[15] Luna, J. S., Santos, A., Lima, M. R. F., Omena, M. C., Mendonça, F. A. C., Bieber, L. W., Sant'Ana, A. E. G., A study of the larvicidal and molluscicidal activities of some medicinal plants from northeast Brazil, J.

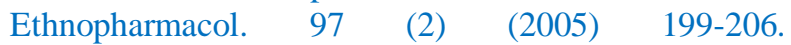
https://doi.org/10.1016/j.jep.2004.10.004.

[16] Adams, R. P., Sparkman, O., Review of identification of essential oil components by gas chromatography/mass spectrometry, J. Am. Soc. Mass

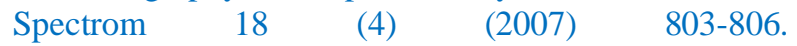
https://doi.org/10.1016/j.jasms.2007.01.001.
[17] Brasil, Ministério da Saúde. Secretaria de Vigilância em Saúde. Departamento de Vigilância Epidemiológica, Vigilância e controle de moluscos de importância epidemiológica: diretrizes técnicas: programa de vigilância e controle da esquistossomose (PCE), Brasília: Ministério da Saúde, 2008. http://portalarquivos.saude.gov.br/images/pdf/2015/ago sto/14/vigilancia-controle-moluscos-import-epidemio2ed.pdf.

[18] Deslandes, N., Técnica de dissecação e exame de planorbídeos, Rev Serv Espec Saúde Pública 4 (1951) 371-382.

[19] Smithers, S. R., Terry, R., The infection of laboratory hosts with cercariae of Schistosoma mansoni and the recovery of the adult worms, Parasitology, 55 (4) (1965) 695-700. https://doi.org/10.1017/s0031182000086248.

[20] Malek, E. A., Snail Hosts of Schistosomiasis and Other Snail-Transmitted Diseases in Tropical America: a manual, American Society of Tropical Medicine and Hygiene, Arlington, 1985. https://doi.org/10.4269/ajtmh.1987.36.199.

[21] McCullough, F. S., Gayral, P., Duncan, J., Christie, J. D., Molluscicides in schistosomiasis control, Bull. World Health Organ. 58 (5) (1980) 681-689. https://www.ncbi.nlm.nih.gov/pmc/articles/PMC23959 $86 /$.

[22] Meyer, B. N., Ferrigni, N. R., Putnam, J. E., Jacobsen, L. B., Nichols, D. E., McLaughlin, J. L., Brine shrimp: a convenient general bioassay for active plant constituents, Planta Med. 45 (1) (1982) 31-34. https://doi.org/10.1055/s-2007-971236.

[23] Amarante, C. B. D., Müller, A. H., Póvoa, M. M., Dolabela, M. F., Phytochemical study bioassay-guided by tests of toxicity on Artemia salina and antiplasmodial activity from stem of aninga (Montrichardia linifera), Acta Amazonica, $41 \quad$ (3) (2011) 431-434. https://doi.org/10.1590/S0044-59672011000300015.

[24] Finney, D.J., Tattersfield, F., Probit Analysis, Cambridge University: Cambridge, 1952.

[25] Mouchrek Filho, V. E., Estudos Analíticos e modificações químicas por metilação e acetilação do eugenol contido no óleo essencial extraído das folhas da espécie Pimenta dioica Lindl, Tese de Doutorado, Universidade de São Paulo, São Paulo, Brasil, 2000.

[26] Gomes, P. R. B., Silva, A. L. S., Pinheiro, H. A., Carvalho, L. L., Lima, H. S., Silva, E. F., Silva, R. P., Louzeiro, H.C., Oliveira, M. B., Mouchrek Filho, V. E., Avaliação da atividade larvicida do óleo essencial do 
Zingiber officinale Roscoe (gengibre) frente ao mosquito Aedes aegypti, Rev. Bras. Plantas Med. 18 (2) (2016) 597-604. https://doi.org/10.1590/1983084x/15_214.

[27] Gomes, P. R. B., Oliveira, R. W. S., Mouchrek Filho, V. E., Nascimento, A. A., Everton, A. P., Louzeiro, H. C., Fontenele, M. A., Activity larvicide of the essential oil Syzygium aromaticum (carnival-ofIndia) in front of the mosquito Aedes aegypti (Linnaeus, 1762). Periodico Tche Quimica 15 (29) (2018) 184-195. http://www.deboni.he.com.br/Periodico29.pdf.

[28] Gomes, P. R. B., Santos, D. P., Mouchrek Filho, V. E., Mendes, L. S. S., Fontenele, M. A., Activity larvicide of the essential oil of Cinnamomum zeylanicum Blume, Period Tche Quimica 16 (31) (2019) 18-26. http://www.deboni.he.com.br/Periodico31.pdf.

[29] Gomes, P. R. B., Silva, A. L. S., Mouchrek Filho, V. E., Mouchrek, A. N., Everton, P. C., Avaliação físicoquímica do óleo essencial Zingiber officinale Roscoe (Gengibre), Rev. Cuba Farm. 50 (3) (2016). http://www.revfarmacia.sld.cu/index.php/far/article/vie w/30/34.

[30] Gomes, P. R. B., Mouchrek Filho, V. E., Ferreira Rabêlo, W., Nascimento, A. A., Costa Louzeiro, H., Lyra, W. S., Fontenele, M. A., Chemical characterization and cytotoxicity of clove essential oil (Syzygium aromaticum), Rev. Colomb. Cienc. Quím. $\begin{array}{lllll}\text { Farm. } & 47 & \text { (1) } & \text { (2018) }\end{array}$ https://doi.org/10.15446/rcciquifa.v47n1.70657.

[31] Campelo, L. M. L., Sá, C. G., Feitosa, C. M., Sousa, G. F., Freitas, R. M., Constituintes químicos e estudos toxicológicos do óleo essencial extraído das folhas de Citrus limon Burn (Rutaceae), Rev. Bras. Plantas Med. $15 \quad$ (4 suppl 1) (2013) 708-716. https://doi.org/10.1590/S1516-05722013000500011.

[32] González-Molina, E., Domínguez-Perles, R., Moreno, D. A., García-Viguera, C., Natural bioactive compounds of Citrus limon for food and health, J. Pharm. Biomed. Anal. 51 (2) (2010) 327-345. https://doi.org/10.1016/j.jpba.2009.07.027.

[33] Mahalwal, V. S., Ali, M., Volatile constituents of the fruits peels of Citrus lemon (Linn) Burm. f. J. Essent. Oil Bear Plants 6 (1) (2003) 31-35. https://doi.org/10.1080/0972-060X.2003.10643325.

[34] Blank, A. F., Costa, A. G., Arrigoni-Blank, M. F., Cavalcanti, S. C. D. H., Alves, P. B., Innecco, R., Ehlert, P. A. D., Sousa, I. F., Influence of season, harvest time and drying on Java citronella (Cymbopogon winterianus Jowitt) volatile oil, Rev. Bras. Farmacogn. 17 (4) (2007)
$557-564$ https://doi.org/10.1590/S0102$695 \times 2007000400014$.

[35] Figueiredo, A. C., Barroso, J. G., Pedro, L. G., Scheffer, J. J. C., Factors affecting secondary metabolite production in plants: volatile components and essential oils, Flavour Fragr. J. 23 (4) (2008) 213-226. https://doi.org/10.1002/ffj.1875.

[36] Cerqueira, M. D., Marques, E. J., Martins, D., Roque, N. F., Cruz, F. G., Guedes, M. L. S., Seasonal variation of the composition of essential oil from Myrcia salzmannii Berg. (Myrtaceae), Quím Nova 32 (6) (2009) 1544-1548. https://doi.org/10.1590/S010040422009000600035 .

[37] Dias, C. N., Moraes, D. F. C., Essential oils and their compounds as Aedes aegypti L. (Diptera: Culicidae) larvicides: review, Parasitol Res. 113 (2) (2014) 565-592. https://doi.org/10.1007/s00436-0133687-6.

[38] Cheng, S., Chang, H. T., Chang, S.T., Tsai, K. H., Chen, W. J., Bioactivity of selected plant essential oils against the yellow fever mosquito Aedes aegypti larvae, Bioresour Technol. $89 \quad$ (1) (2003) 99102.https://doi.org/10.1016/S0960-8524(03)00008-7.

[39] Fernandez, C. M. M., Barba, E. L., Fernandez, A. C. M., Cardoso, B. K., Borges, I. B., Takemura, O. S., Martins, L. A., Cortez, L. E. R., Cortez, D. A. G., Gazim, Z. C., Larvicidal activity of essential oil from Tetradenia riparia to control of Aedes aegypti larvae in function of season variation, J. Essent. Oil Bear Plants 17 (5) (2014) 813-823.

https://doi.org/10.1080/0972060X.2014.892841.

[40] Leyva, M., Marquetti, M. C., Tacoronte, J. E., Scull, R., Tiomno, O., Mesa, A., Montada, D., Actividad larvicida de aceites esenciales de plantas contra Aedes aegypti (L.) (Diptera: Culicidae), Rev. Biomed. 20 (1) (2009)

5-13. http://revistabiomedica.mx/index.php/revbiomed/articl e/view/529.

[41] Lee, H. S., Mosquito larvicidal activity of aromatic medicinal plant oils against Aedes aegypti and Culex pipiens pallens, J. Am. Mosq. Control Assoc. 22 (2) (2006) 292-296. https://doi.org/10.2987/8756971X(2006)22[292:MLAOAM]2.0.CO;2.

[42] Leite, A. M., Lima, E. O., Souza, E. L., Diniz, M. D. F., Leite, S. P., Xavier, A. L., Medeiros, I. A. D., Preliminary study of the molluscicidal and larvicidal properties of some essential oils and phytochemicals from medicinal plants, Rev. Bras. Farmacogn. 19 (4) (2009) 842-846. https://doi.org/10.1590/S0102$695 \times 2009000600008$. 
[43] Lucia, A., Audino, P. G., Seccacini, E., Licastro, S., Zerba, E., Masuh, H., Larvicidal effect of Eucalyptus grandis essential oil and turpentine and their major components on Aedes aegypti larvae, J. Am. Mosq. Control Assoc. 23 (3) (2007) 299-304. https://doi.org/10.2987/8756-

971X(2007)23[299:LEOEGE]2.0.CO;2.

[44] Campolo, O., Romeo, F. V., Algeri, G. M., Laudani, F., Malacrinò, A., Timpanaro, N., Palmeri, V. Larvicidal effects of four citrus peel essential oils against the arbovirus vector Aedes albopictus (Diptera: Culicidae), J. Econ. Entomol. 109 (1) (2015) 360-365. https://doi.org/10.1093/jee/tov270.

[45] Giatropoulos, A., Papachristos, D. P., Kimbaris, A., Koliopoulos, A., Polissiou, M. G., Emmanouel, N., Michaelakis, A., Evaluation of bioefficacy of three Citrus essential oils against the dengue vector Aedes albopictus (Diptera: Culicidae) in correlation to their components enantiomeric distribution, Parasitol. Res. $111 \quad$ (6) 2253-2263. https://doi.org/10.1007/s00436-012-3074-8.

[46] Amer, A., Mehlhorn, H., Larvicidal effects of various essential oils against Aedes, Anopheles, and Culex larvae (Diptera, Culicidae), Parasitol. Res. 99 (4) (2006) 466-472. https://doi.org/10.1007/s00436-0060182-3.

[47] Petersen, P. E., World Health Organization. Organisation Mondiale de la Sante, Community Dent. Oral Epidemiol. $31 \quad$ (6) (2003) 471-471. https://doi.org/10.1046/j.1600-0528.2003.00124.x.

[48] Silva, T., Batista, M., Camara, C., Agra, M., Molluscicidal activity of some Brazilian Solanum spp. (Solanaceae) against Biomphalaria glabrata, Ann. Trop. Med. Parasitol. 99 (4) (2005) 419-425. https://doi.org/10.1179/136485905X36208.

[49] Silva, C. L. P. A. C., Vargas, T. S., Baptista, D. F., Molluschicidal activity of Moringa oleifera on Biomphalaria glabrata: integrated dynamics to the control of the snail host of Schistosoma mansoni, Rev. Bras. $\quad$ Farm. $23 \quad$ (2013) 848-850. https://doi.org/10.1590/S0102-695X2013000500019.

[50] Silva, T., Silva, T., Martins, R., Maia, G. L. A., Cabral, A. G. S., Camara, C. A., Agra, M. F., BarbosaFilho, J. M., Molluscicidal activities of six species of Bignoniaceae from north-eastern Brazil, as measured against Biomphalaria glabrata under laboratory conditions, Ann. Trop. Med. Parasitol. 101 (4) (2007) 359-365. https://doi.org/10.1179/136485907X176427.

[51] Coutinho, D. F., Dias, C. S., Barbosa-Filho, J. M., Agra, M. F., Martins, R. M., Silva, T. M., Cunha, E. V.
L., Silva, M. S., Craveiro, A. A., Composition and molluscicidal activity of the essential oil from the stem bark of Ocotea bracteosa (Meisn.) Mez, J. Essent. Oil Res. $\quad 19 \quad$ (5) (2007) 482-484. https://doi.org/10.1080/10412905.2007.9699958.

[52] Farmacopeia Brasileira, Editora Atheneu, parte I-II, quinto fascículo, São Paulo, $4^{\mathrm{a}}$ ed., 2004.

[53] Gomes, P. R. B., Reis, J. B., Fernandes, R. P., Mouchrek Filho, V. E., Souza, A. G., Fontenele, M. A., Silva, J. C., Toxicidad y Actividad Molusccidal del Aceite Esencial Pimenta dioica Contra El Caracol Biomphalaria glabrata. Revista Peruana de Biología 26 (1) (2019)

101-8. https://doi.org/10.15381/rpb.v26i1.15913.

[54] Chaar, J. S., Estudos analíticos e modificação química por acetilação do linalol contido no óleo essencial da espécie Aniba duckei Kostermans, Tese de Doutorado, Universidade de São Paulo, São Paulo, Brasil, 2000. https://doi.org/10.11606/T.75.2000.tde28112001-085626. 